\title{
ARTICULANDO INSTRUMENTOS JURÍDICOS PARA A ECO CIDADANIA E CONTROLE SOCIAL DA VULNERABILIDADE MULTIDIMENSIONAL
}

\author{
ARTICULATING LEGAL INSTRUMENTS FOR THE \\ ECO-CITIZENSHIP AND SOCIAL CONTROL OF \\ MULTIDIMENSIONAL VULNERABILITY
}

\author{
BRISA ARNOUD DA SILVA ${ }^{1}$
}

\begin{abstract}
RESUMO: O artigo examina a premência de mudança de paradigma diante da percepção dos efeitos reflexos da Modernidade Reflexiva da Sociedade de Risco e da estreita relação entre as adversidades sociais e ambientais. O objetivo central visa aglutinar esforços para combater a dinâmica do modelo de desenvolvimento liberal que desencadeia crises generalizadas, que reagem em cadeia. Para tanto, analisa-se a implementação conjugada de instrumentos jurídicos, dentre o direito ao ambiente, direito à saúde, direito à alimentação, o princípio do Mínimo Existencial Ecológico, a responsabilidade da pessoa jurídica, a responsabilidade do Estado, o direito à informação ambiental, o direito à participação, articulados pelo seu caráter interdependente e com o propósito de enfrentar a vulnerabilidade socioambiental multidimensional, que atinge a todos, mas sobretudo os mais vulneráveis. Nesse diapasão, aborda-se o controle social e o auxílio dos movimentos de representação social com as causas comuns de interesse coletivo, na cooperação e inter-relação das demandas das comunidades mais carentes, que vivem a condição de vulnerabilidade em dimensão generalizada, refletindo o caráter de injustiça ambiental. Por fim, trata-se da expectativa do paradigma de eco cidadania, propondo uma resposta emancipatória e sustentável à modernização reflexiva, baseada na transformação cultural que precisa ser assumida para garantir nosso direito ao futuro, envolvendo o homem na preservação da vida em todas as suas formas e na reforma desse modelo de desenvolvimento de tendência destrutiva e egoísta. O método ${ }^{2}$ utilizado na
\end{abstract}

Artigo recebido em 31.07.2015. Pareceres emitidos em 16.08.2015, 11.09.2015 e 13.10.2015.

Artigo aceito para publicação em 30.10.2015.

${ }^{1}$ Mestre em Ciência Jurídica no Programa de Pós-graduação stricto sensu em Ciência Jurídica da Universidade do Vale do Itajaí - Univali/SC. Advogada, Especializada em Direito do Estado pela Universidade Anhanguera - Uniderp. Extensão em Instrumentos de Gestão Ambiental Empresarial pela Fundação Getúlio Vargas - FGV. brisa_arnoud@hotmail.com

2 "Método é forma lógico-comportamental na qual se baseia o Pesquisador para investigar, tratar os dados colhidos e relatar os resultados". PASOLD, Cesar Luiz. Metodologia da Pesquisa Jurídica: Teoria e Prática. 11. ed., Florianópolis: Conceito Editorial/Millenium, 2008. p. 85. 
elaboração desta investigação foi o indutivo, com as técnicas do referente ${ }^{3}$, categoria $^{4}$, conceitos operacionais ${ }^{5}$, pesquisa bibliográfica ${ }^{6}$ e fichamento ${ }^{7}$.

PALAVRAS-CHAVES: Modernidade Reflexiva; Vulnerabilidade Socioambiental; Controle Social; Participação Social; Eco Cidadania.

ABSTRACT: The article examines the urgency of paradigm shift on the perception of the reflex effects of Reflexive Modernity of Risk Society and the close relationship between the social and environmental adversities. The main objective aims to unite efforts to combat the dynamics of liberal development model which triggers generalized crises, which react in the chain. Therefore, it analyzes the implementation of legal instruments, conjugate among the right to the environment, the right to health, the right to food, the principle of minimum ecological existential, the liability of a legal person, the responsibility of the State, the right to environmental information, the right to participation, articulated by its interdependence and in order to face the multidimensional socio-environmental vulnerability, which affects everyone, but especially the most vulnerable. In this diapason, it approaches the social control and the help of movements of social representation with the common causes of collective interest, cooperation and inter-relation of the demands of the most needy, who live the condition of vulnerability in generalized dimension, reflecting the character of environmental injustice. Finally, it delas with the expectation of the paradigm of eco-citizenship, proposing an emancipatory and sustainable response to reflexive modernization, based on the cultural change that needs to be taken to ensure our right to future involving the man in the preservation of life in all its ways and reform this development destructive and selfish tendency model. The method used in the preparation of this research was the inductive, with the techniques of related, category, operational concepts, bibliographical research and book report.

KEYWORDS: Modernity Reflective; Social and Environmental Vulnerability; Social Control; Social Participation; Eco-citizenship.

SUMÁRIO: Introdução; 1. A Modernidade Reflexiva Refletindo a Crise Socioambiental; 2. Instrumentos Jurídicos Associados para a Melhor Compreensão do Estado Socioambiental de Direito; 3. O Direito Essencial à Informação e à Participação para o Controle Social; 4. A Proposta da Eco Cidadania; Considerações Finais; Referências.

\footnotetext{
3 "Explicação prévia do motivo, objetivo e produto desejado, delimitado o alcance temático e de abordagem para uma atividade intelectual, especialmente para uma pesquisa". PASOLD, Cesar Luiz. Metodologia da Pesquisa Jurídica: Teoria e Prática. 11. ed., Florianópolis: Conceito Editorial/ Millenium, 2008. p. 54.

4 "Palavra ou expressão estratégica à elaboração e/ou expressão de uma ideia". PASOLD, Cesar Luiz. Metodologia da Pesquisa Jurídica: Teoria e Prática. 11. ed., Florianópolis: Conceito Editorial/ Millenium, 2008. p. 25.

5 "Definição estabelecida ou proposta para uma palavra ou expressão, com o propósito de que tal definição seja aceita para os efeitos das ideias expostas". PASOLD, Cesar Luiz. Metodologia da Pesquisa Jurídica: Teoria e Prática. 11. ed., Florianópolis: Conceito Editorial/Millenium, 2008. p. 37. 6 "Técnica de investigação em livros, repertórios jurisprudenciais e coletâneas legais". PASOLD, Cesar Luiz. Metodologia da Pesquisa Jurídica: Teoria e Prática. 11. ed., Florianópolis: Conceito Editorial/Millenium, 2008. p. 103.

7 "Técnica que tem como principal utilidade otimizar a leitura na Pesquisa Científica, mediante a reunião de elementos selecionados pelo Pesquisador que registra e/ou resume e/ou reflete e/ou analisa de maneira sucinta, uma Obra, um Ensaio, uma Tese ou Dissertação, um Artigo ou uma aula, segundo Referente previamente estabelecido". PASOLD, Cesar Luiz. Metodologia da Pesquisa Jurídica: Teoria e Prática. 11. ed., Florianópolis: Conceito Editorial/Millenium, 2008. p. 107.
} 
SUMMARY: Introduction; 1 . The Reflective Modernity Reflecting the Socioenvironmental Crisis; 2. Associated Legal Tools for Better Understanding the Socio-Environmental State of Law; 3. The Essential Right to Information and Participation for Social Control; 4. The Proposal of Eco-citizenship; Final Considerations; References.

\section{INTRODUÇÃO}

O presente artigo visa examinar a articulação de instrumentos jurídicos, com fulcro nos objetivos do Estado Socioambiental de Direito, para auxiliar a resolução de conflitos socioambientais.

A problemática se estabelece diante da percepção da dependência da multidimensionalidade do ambiente complexo, e da consequente inter-relação das desigualdades na atual modernidade reflexiva da Sociedade de Risco.

Logo, a pesquisa analisa o contexto da modernidade reflexiva da Sociedade de Risco e relaciona o reconhecimento constitucional de direitos humanos, fundamentais, sociais e do ambiente, como ferramenta para o combate da crise socioambiental.

Por fim, compõe o direito à informação, à participação e o auxílio dos movimentos de representação social à promover o combate da vulnerabilidade generalizada e estimular a eco cidadania.

O que se fomenta com esse trabalho é um conhecimento que traz em si uma oportunidade de manifestação ativa, promovendo a conscientização crítica, transformadora e participativa da sociedade sobre a necessidade de preservar o ambiente para a existência digna da humanidade, aspirando um modo de vida mais sustentável.

\section{A MODERNIDADE REFLEXIVA REFLETINDO A CRISE SOCIOAMBIENTAL}

Nesse primeiro momento apresenta-se a Teoria da Modernização Reflexiva de Anthony Giddens, Scott Lash e Ulrich Beck, descrevendo aspectos da desigualdade socioambiental na Sociedade de Risco, destacando o caráter interdependente e multidimensional da complexidade ambiental, relatando como a interferência na qualidade ambiental reflete diretamente na qualidade de vida.

Muitos dos efeitos e fenômenos ditos "imprevisíveis" que ocorrem na nossa atualidade têm a gênese de suas ameaças no próprio homem, no seu comportamento e ânsia pelo desenvolvimento.

Apesar dos incontestáveis avanços promovidos pela Revolução Industrial, que evidentemente inovou, sofisticou e impulsionou a ascensão de todos os setores e transformou o modo de vida, a atual Sociedade de Risco constata os resultados do desenvolvimento industrial de crescimento a todo custo. A expressão "Sociedade de Risco" traduz esse estado de vulnerabilidade, de iminente desgraça e riscos pluridimensionais desencadeados pelos efeitos 
imprevisíveis da ação cumulada, predatória e inconsequente do modelo de produção e consumo da sociedade industrial, capaz de pôr em xeque o futuro da humanidade e a vida na Terra ${ }^{8}$.

Esse estado de vulnerabilidade que vivemos se reverbera por toda sociedade, relacionado às crises econômicas, crises de representatividade, crises ecológicas, crises bélicas, numa propagação do conflito na Sociedade de Risco.

Em virtude disso, torna-se necessário abordar o panorama percebido por Anthony Giddens, Scott Lash e Ulrich Beck no livro "Modernização reflexiva: política, tradição e estética na ordem social moderna" (1997), que explana acerca da reflexividade dos nossos atos, e, ao mesmo tempo, desperta a emergência da modificação do perfil de sociedade moderna, para uma reforma de racionalidade.

Faz-se distinção à teoria da Modernização Reflexiva justamente porque não se limita a percepção dos efeitos reflexos da Sociedade de Risco, mas questiona essa política desenvolvimentista que provoca auto confrontação com efeitos reflexos na Sociedade de Risco ${ }^{9}$, ou seja, uma reflexão a partir da reflexividade, à instigar uma potencial reação social para a mudança ${ }^{10}$.

Assim, a teoria da Modernização Reflexiva pondera não apenas no sentido da reflexividade, que provoca autoconfrontação pelos efeitos da ação, mas também a potencial reflexão.

Os efeitos reflexos na modernidade reflexiva projetam-se de duas formas: pela reflexividade estrutural, em que a ação reflete as regras e recursos da estrutura social, e a autorreflexividade, em que a ação reflete à, e, em si mesma ${ }^{11}$.

\footnotetext{
${ }^{8}$ FREITAS, Juarez. Sustentabilidade: direito ao futuro. Belo Horizonte: Editora Fórum, 2011, p. 27.

${ }^{9}$ LEITE, José Rubens Morato; BELCHIOR, Germana Parente Neiva. Dano Ambiental na Sociedade de Risco: uma visão introdutória. In: FERREIRA, Heline Sivini; FERREIRA, Maria Leonor Paes Cavalcanti (Org.). Dano Ambiental na Sociedade de Risco. São Paulo: Saraiva, 2012. p. 15: "Notadamente, a sociedade pós-moderna produz riscos que podem ser controlados e outros que escapam ou neutralizam os mecanismos de controle típicos da sociedade industrial. A sociedade de risco revela-se, portanto, um modelo teórico que marca a falência da modernidade, emergindo de um período pós-moderno, à medida que as ameaças produzidas ao longo da sociedade industrial começam a tomar forma. Os pilares da concepção moderna de civilização já não conseguem mais explicar os desenvolvimentos da ciência e da sociedade. Trata-se de uma crise de paradigma, uma crise própria da modernidade. Referida crise torna praticamente inviável, pelo menos nos moldes clássicos, qualquer tentativa do homem pós-moderno no sentido de calcular os riscos e os desafios a que se submete o meio ambiente no século XXI"; GIDDENS, Anthony. Mundo em Descontrole: o que a globalização está fazendo de nós. 6. ed., Tradução de Maria Luiza X. de A. Borges. Título original: Runaway World. Rio de Janeiro: Record, 2007, p. 95: "A sociedade de risco se caracteriza por novas incertezas, por crescente individualismo e por mudanças básicas nas instituições sociais mais importantes".

${ }^{10}$ GIDDENS, Anthony; BECK, Ulrich; LASH, Scott. Modernização Reflexiva: política, tradição e estética na ordem social moderna. Tradução de Magda Lopes. São Paulo: Editora da Universidade Estadual Paulista, 1997. Título original: Reflexive Modernization: politics, tradition and aesthetics in the modern social order. p. 13-14.

${ }^{11}$ GIDDENS, Anthony; BECK, Ulrich; LASH, Scott. Modernização Reflexiva: política, tradição e estética na ordem social moderna. Tradução de Magda Lopes. São Paulo: Editora da Universidade
} 
Isso significa que toda ação tem uma reação, ou tudo que vai, volta, e "what goes around, comes around". Uma ação inconsequente, redundantemente, provoca uma reação que não se podem prever os efeitos. Consequências maléficas desencadeadas repercutem por todas as dimensões da vida e atingem a todos indiscriminadamente na Sociedade de Risco (ainda que de forma desigual), e no que constrange, impulsiona a transformação das regras e recursos da estrutura social.

Pedro Jacobi ressalta que na modernidade reflexiva têm-se a possibilidade, não apenas de reconhecer que a própria sociedade é geradora de efeitos reflexos danosos, mas sobretudo, de tornarmo-nos mais autocríticos, porque ao mesmo tempo em que "a humanidade gera perigos, reconhece os riscos que produz e reage diante disso"12.

Isso permite esclarecer como o reflexo da política de crescimento faz a própria população refém do efeito bumerangue, que dissemina problemas socioambientais, que atingem a todos, mas sobretudo, os mais vulneráveis.

Ulrich Beck, em "La sociedad del riesgo: hacia uma nueva modernidad", expondo sobre a difusão do efeito social de bumerangue, mostra que os próprios atores da modernização, mais cedo ou mais tarde, são atingidos, de formas diversas, pelos perigos que desencadeiam ${ }^{13}$.

A modernização reflexiva entendida do ponto de vista dos efeitos sobre o sujeito indica que uma ação promovida por este recai novamente sobre ele mesmo, tal como um bumerangue. Os próprios agentes responsáveis pelo processo de contaminação são igualmente afetados por ela ${ }^{14}$.

No cenário em que a degradação ambiental cerca a pobreza e os mais vulneráveis, a desigualdade revela como reflexo da Sociedade de Risco ${ }^{15}$, que interfere em todo projeto de vida ${ }^{16}$, reage em cadeia e provoca efeitos na

\footnotetext{
Estadual Paulista, 1997. Título original: Reflexive Modernization: politics, tradition and aesthetics in the modern social order, p. 141.

12 JACOBI, Pedro. Educar na Sociedade de Risco: o desafio de construir alternativas. Faculdade de Educação da USP e PROCAM-USP. Revista em Educação Ambiental, v. 2, nº 2, p. 49-65, 2007. p. 55. Disponível em: <http://www.revistas.usp.br/pea/article/view/30029>. Acesso em: 06 dez. 2014.

13 BECK, Ulrich. La Sociedad del Riesgo: hacia uma nueva modernidade. Título original: Risikogesellschaft. Auf dem Weg in eine andere Moderne. Barcelona: Ediciones Paidós Ibérica, S.A., 2006. p. 53.

${ }^{14}$ DEMAJOROVIC, Jacques. Sociedade de Risco e Responsabilidade Socioambiental: perspectivas para a educação corporativa. São Paulo: Editora Senac, 2003. p. 40-41.

${ }_{15}$ SILVA, Brisa Arnoud da. Uma Análise sobre a Modernidade Reflexiva e a Complexidade Ambiental no Estado Socioambiental de Direito. Revista Cadernos do Programa de Pós-Graduação em Direito/UFRGS, v. 10, $\mathrm{n}^{\circ} 2$ (2015). Disponível em: <http://seer.ufrgs.br/index.php/ppgdir/article/ view/54612>. Acesso em: 07 nov. 2015.

${ }^{16}$ AYALA, Patryck de Araújo; WENER, Eveline de Magalhães. O Estado Socioambiental e o Dever de Proteção de Projetos de Vida Sustentáveis. Revista Direito Ambiental e Sociedade. Universidade de Caxias do Sul, vol. 1, n² 2, p. 211-228, jul./dez., Caxias do Sul, RS: Educs, 2011.
} 
dimensão social, cultural, econômica/financeira, jurídica, política e ambiental ${ }^{17}$, e uma análise limitada sobre pobreza, restrita a padrões de vida e nível de renda ${ }^{18}$, não percebe a intensidade dessa desigualdade socioambiental, que dificulta as possibilidades de desenvolvimento humano, viola direitos e expõe os que tem mais dificuldade de reação à situação de risco e insegurança ${ }^{19}$.

O nexo entre pobreza e ambiente e bem-estar e ambiente tornam-se evidentes quando se percebe a maior dependência ao ambiente e sensibilidade à degradação ambiental dessas comunidades mais carentes, socialmente vulneráveis, porque contam mais com os bens e recursos e serviços ecossistêmicos para a sobreviver ${ }^{20}$, e descortinar essa realidade e admitir a complexidade $^{21}$, sob o olhar da Ecologia Profunda, que assume a interdependência e multidimensionalidade do todo $^{22}$, permite compreender como as múltiplas implicações dos efeitos reflexos no ambiente provocam múltiplas implicações na dimensão social ${ }^{23}$.

A ênfase na interdisciplinaridade da análise das questões ambientais deve-se à constatação de que os problemas que afetam e mantêm a vida no nosso planeta são de natureza global e que suas causas não podem restringir-se apenas aos fatores estritamente biológicos, revelando dimensões políticas, econômicas, institucionais, sociais e culturais ${ }^{24}$.

Como resultado, condições ambientais prejudiciais tornam-se verdadeiros obstáculos à possibilidade de uma vida digna, que manifestam e viabilizam

\footnotetext{
Nesse sentido, WERNER e AYALLA ressaltam que o dano ao projeto de vida "implica a perda ou sensível redução das oportunidades de desenvolvimento do indivíduo, de uma forma irreparável ou muito dificilmente reparável. As violações de direitos que causam esse dano ao projeto de vida impedem a obtenção de um resultado. Assim, a própria existência da pessoa é alterada por fatores alheios a ela, impostos de modo injusto e arbitrário". p. 218-219.

${ }^{17}$ CRUZ, Paulo Márcio; BODNAR, Zenildo. Globalização, Transnacionalidade e Sustentabilidade. Itajaí: UNIVALI, 2012. Disponível em: <http://www.univali.br/ppcj/ebook>. Acesso em: 21 jul. 2014 p. 28.

${ }^{18}$ HIROSHI, Setooka (Homazawa University, Japan). Increasing Inequality and Poverty Today: on the understanding of the essence of poverty. In: Fórum da Associação Mundial de Economia Política. 8. 2013. Florianópolis. Painel Inequality in Latin America.

${ }^{19}$ DEMO, Pedro. Charme da Exclusão Social. Campinas, SP: Autores Associados, 1998. p. 103.

${ }^{20}$ CORREA, Esmeralda. Qual a Relação entre Pobreza e Meio Ambiente? Evidências e Reflexões desde uma Perspectiva Multidimensional do Bem-estar Humano. Disponível em: <www.pucrs.br/ eventos/alcadeca/download/pobreza-e-meio-ambiente.doc>. Acesso em: 23 jan. 2015.

${ }^{21}$ SILVA, Brisa Arnoud da. A Importância do Mínimo Existencial Ecológico para a Concretização do Estado Democrático de Direito. Revista Justiça do Direito, v. 28, no 1, p. 84-107, jan./jun. 2014, p. 86. Disponível em: <www.upf.br/seer/index.php/rjd/article/download/4832/3259>. Acesso em: 12 maio 2015.

${ }^{22}$ CAPRA, Fritjof. A Teia da Vida: uma compreensão científica dos sistemas vivos. São Paulo: Editora Cultrix: 1996. p. 28.

${ }^{23}$ FAGÚNDEZ, Paulo Roney Ávila. O Direito e a Hipercomplexidade. São Paulo: LTr, 2003. p. 20.

${ }^{24}$ JACOBI, Pedro. Educar na Sociedade de Risco: o desafio de construir alternativas. Faculdade de Educação da USP e PROCAM-USP. Revista em Educação Ambiental, v. 2, nº 2, p. 49-65, 2007. p. 60. Disponível em: <http://www.revistas.usp.br/pea/article/view/30029>. Acesso em: 06 dez. 2014.
} 
a violação de direitos fundamentais multidimensionais, principalmente quando se identifica essa inter-relação das desigualdades, que em virtude da desigualdade social também sujeita-se à uma desigual exposição aos riscos ambientais, que provoca e propaga a injustiça ambiental ${ }^{25}$.

Para visualizar esse cenário da vulnerabilidade socioambiental e como a interferência na qualidade ambiental afeta a vida das pessoas, remonta-se como exemplo o contexto do sertão nordestino, que foi muito explorado no século XVI e XVII pelo cultivo da cana-de-açúcar, mas também muito prejudicado pelos desmatamentos e queimadas excessivas, e pela característica peculiar do cultivo de cana-de-açúcar que tende a secar o solo e os lençóis freáticos, e a própria cana seca não reverte em nenhuma umidade para o ambiente, onde o reflexo hoje é a falta de água nessa região, que, como num círculo, desencadeia a desnutrição, que desencadeia a baixa escolaridade, que desencadeia no trabalho infantil... e assim sucessivamente ${ }^{26}$.

A favela também mostra, apesar do atual fenômeno de glamourização da favela ${ }^{27}$, uma cumulação de problemas, onde as pessoas, por não ter onde morar se instalam em áreas geograficamente problemáticas, em encostas de

25 CAVEDON, Fernanda de Salles; VIEIRA, Ricardo Stanziola. Conexões entre Desastres Ecológicos, Vulnerabilidade Ambiental e Direitos Humanos: novas perspectivas. Revista de Direito Econômico e Socioambiental, Curitiba, v. 1, nº 1, p. 179-206, jan./jun. 2011. p. 186-188.

${ }^{26}$ GALEANO, Eduardo. As Veias Abertas da América Latina. Tradução de Galeano de Freitas, 12 ed., Rio de Janeiro: Paz e Terra, 1981. Título original: Las Venas Abiertas de America Latina. p. 74-77.

${ }_{27}$ Discrepante da cultura do medo (que evidencia, por um lado, o estado de alarme social associada ao crime e violência, e por outro a segregação social que valoriza a desigualdade e a separação, e estigmatiza grupos considerados perigosos em referência à etnia, ao local de moradia, a condição financeira, e presume que negros e pobres são mais propensos ao crime, considerando pobreza, juventude, cor negra, e moradia na favela prenunciação de marginalidade. PASTANA, Débora Regina. Cultura do Medo e Democracia: um paradoxo brasileiro. Disponível em: <http://www.uel.br/revistas/uel/index.php/mediacoes/article/download/2172/18>. Acesso em: 28 abr. 2015), e diferente da glorificação da miséria (tema recorrente do Cinema Novo da década de 60, que enfrenta o discurso da vitimização do povo, e assume e invoca-o como agente revolucionário de transformação social. BENTES, IVANA. Terra de Fome e Sonho: o país material de Glauber Rocha. Disponível em: <http://www.bocc.ubi.pt/pag/bentes-ivana-glauber-rocha.html>. Acesso em 15 maio 2015; ROCHA, Glauber. Eztetyka da Fome. Disponível em: <http://www. tempoglauber.com.br/t_estetica.html>. Acesso em: 19 maio 2015), a glamourização da favela é a mudança na forma como se vê a favela, mas sob a camuflagem e ignorância dos distúrbios de desigualdade social, como a falta de infraestrutura e violência do narcotráfico, fabricando - com o auxílio da dramaturgia midiática - uma realidade distorcida, e até mesmo romântica, de satisfação e atração do exótico da periferia, a fim de fomentar a exploração da "nova favela", sem que haja, ou tenha havido, a superação dos velhos problemas (BENTES, Ivana. O copyright da miséria e os discursos sobre a exclusão. Lugar Comum n 17, p. 85-95. Disponível em: <http://s3.amazonaws. com/academia.edu.documents/30467869/11_o_copyright_da_miseria_e_os_discursos_sobre_a exclusao.pdf?AWSAccessKeyld=AKIAJ56TQJRTWSMTNPEAAExpires $=\overline{1} 431633466 \& \bar{S}$ ignature $=$ a3jliu2UGGEVxRblwGkqH4d7EZ4\%3D\&response-content-disposition=inline>. Acesso em: 19 maio 2015; FREIRE-MEDEIROS, Bianca. A Favela e seus Trânsitos Turísticos. Observatório de Inovação do Turismo - Revista Acadêmica, vol. II, nº 2, jun. 2007. Disponível em: <http://bibliotecadigital. fgv.br/ojs/index.php/oit/article/view/5664>. Acesso em: 19 maio 2015. 
morros, nas margens de rios, nas cercanias de depósitos de lixos, expostos a deslizamentos, alagamentos, doenças, à violência, que demostra essa situação de discriminação, desamparo e violação da dignidade humana ${ }^{28}$.

\section{INSTRUMENTOS JURÍDICOS ASSOCIADOS PARA A MELHOR COMPREENSÃO DO ESTADO SOCIOAMBIENTAL DE DIREITO}

Nesse tópico abordam-se alguns instrumentos jurídicos, analisados a partir da multidimensionalidade e interdependência dos direitos humanos e fundamentais, sociais e do ambiente, para o enfrentamento das debilidades socioambientais em caráter de controle social.

Mas para falar nesses instrumentos, primeiro é preciso tratar a evolução do Estado Social e ambiental - Socioambiental de Direito brasileiro, que se desenvolveu diante da preocupação da própria sociedade com a degradação ambiental, e com o reconhecimento constitucional do direito ao ambiente se exprime a condição de superação de concepções desenvolvimentistas liberais estreitas e o reconhecimento da importância vital do ambiente ecologicamente equilibrado para a vida digna e desenvolvimento humano ${ }^{29}$.

$\mathrm{O}$ ambiente tem diversas tratativas inseridas na CRFB/88, previsto em capítulo próprio, no Capítulo VI "Do Meio Ambiente", no Título VIII, "Da Ordem Social".

E apesar da previsão do direito ao ambiente não constar no rol do Título II da CRFB/88, que trata expressamente "Dos Direitos e Garantias Fundamentais", é pacífico entender o ambiente um direito fundamental, na medida em que se definem direitos fundamentais as normas jurídicas positivas, de nível constitucional, que refletem os valores mais importantes de uma sociedade, visando a dignidade e integridade humana, núcleo essencial dos direitos fundamentais ${ }^{30}$, uma vez que não se contesta que o "quadro de destruição ambiental no mundo compromete a possibilidade de uma existência digna para a humanidade e põe em risco a própria vida humana"31.

Assim, o Direito Ambiental pode ser definido como um direito que se desdobra em três vertentes, composto pelo direito ao ambiente, direito sobre o ambiente e direito do ambiente, dado que é um direito fundamental que

\footnotetext{
${ }^{28}$ OBSERVATÓRIO DE FAVELAS. Do "perigoso" ao Exotismo: faces da mesma moeda. Disponível em: <http://observatoriodefavelas.org.br/noticias-analises/do-perigo-ao-exotismo-facesda-mesma-moeda/>. Acesso em: 25 maio 2015.

${ }^{29}$ SILVA, Brisa Arnoud da. Do Estado Liberal para Socioambiental de Direito: o caminho para o desenvolvimento sustentável. In: SOUZA, Maria Claudia da Silva Antunes de; ARMADA, Charles Alexandre Souza (Org.). Teoria Jurídica e Transnacionalidade. Vol. II, p. 129-152, p. 130-132. Disponível em: <http://www.univali.br/ppcj/ebook>. Acesso em: 21 jul. 2014.

${ }^{30}$ LOPES, Ana Maria D'Avila. O Direito Fundamental à Biodiversidade e o Patenteamento de Espécies Vivas. Revista de Informação Legislativa, v. 43, n 172, p. 57-72, out./dez. 2006. Disponível em: <http://uww2.senado.leg.br/bdsf/bitstream/handle/id/92830/Lopes\%20Ana\%20Maria.pdf?sequence=4>. Acesso em: 21 jul. 2014.

${ }^{31}$ Nesse sentido Mirra (apud MACHADO, Paulo Affonso Leme. Direito Ambiental Brasileiro. 16. ed., São Paulo: Malheiros, 2008, p. 125).
} 
cumpre a função de conciliar os direitos à sadia qualidade de vida, o desenvolvimento econômico e a proteção dos recursos naturais ${ }^{32}$.

Essa forma de conciliar os direitos ao ambiente ${ }^{33}$, os sociais ${ }^{34}$ e da livre iniciativa $^{35}$, representa o esforço e o compromisso mundial pela proteção social e ambiental para a sadia qualidade de vida, aderindo o desenvolvimento sustentável, inclinado à garantir um mínimo existencial socioambiental, que sustenta a concepção de pleno desenvolvimento humano.

O tema do desenvolvimento sustentável sobrevêm com o entendimento de um desenvolvimento homeostático, equilibrado, não apenas no sentido de suprir as necessidades do presente sem comprometer o futuro, como introduziu o Relatório Nosso Futuro Comum de 1987, mas sobretudo, para garantir o máximo de qualidade possível, material e imaterial, a vida de todos, respeitando a multidimensionalidade das condições de vida ${ }^{36}$.

Porque assim como há a necessidade de um conjunto de condições materiais mínimas em termos sociais (como saúde, alimentação, moradia, educação), sem as quais o pleno desenvolvimento humano e mesmo a inserção política do indivíduo na comunidade são inviabilizadas, também na seara ecológica há um conjunto de condições mínimas, em termos de qualidade ambiental, sem os quais se prejudica o desenvolvimento e mesmo a integridade física do indivíduo, na contramão do comando constitucional que impõe o dever do Estado de tutelar a vida e a dignidade humana, conforme os arts. $5^{\circ}$ e $1^{\circ}$, um dos fundamentos do Estado Democrático de Direito ${ }^{37}$.

Nesse sentido, o Superior Tribunal de Justiça - STJ adota o Princípio do Mínimo Existencial Ecológico para fundamentar suas decisões dirigindo para uma tutela mais efetiva do direito à sadia qualidade de vida:

Postula que, por trás da garantia constitucional do mínimo existencial, subjaz a ideia de que a dignidade da pessoa humana está intrinsecamente relacionada à qualidade ambiental. Ao conferir dimensão ecológica ao núcleo normativo, assenta a premissa de que não existe patamar mínimo de bem-estar sem respeito ao direito fundamental do meio ambiente sadio $^{38}$.

\footnotetext{
${ }^{32}$ ANTUNES, Paulo de Bessa. Direito Ambiental. 7. ed., Rio de Janeiro: Lumen Juris, 2004. p. 11.

${ }^{33}$ Art. 225, CRFB/88.

${ }^{34}$ Art. $6^{\circ}$, CRFB/88 (a educação, a saúde, a alimentação, o trabalho, a moradia, o lazer, a segurança, a previdência social, a proteção à maternidade e à infância, a assistência aos desamparados).

${ }^{35}$ Também na CRFB/88, nos arts. $1^{\circ}$ e 170.

${ }^{36}$ FREITAS, Juarez. Sustentabilidade: direito ao futuro. Belo Horizonte: Editora Fórum, 2011. p. 47-49.

${ }^{37}$ FENSTERSEIFER, Tiago. Direitos Fundamentais e Proteção do Ambiente: a dimensão ecológica da dignidade humana no marco jurídico-constitucional do Estado Socioambiental de Direito. Porto Alegre: Livraria do Advogado Editora, 2008, p. 270-271.

${ }^{38}$ Disponível em: http://stj.jus.br/portal_stj/publicacao/engine.wsp?tmp.area=398\&tmp.texto=97483. Acesso em: 15 jan. 2015.
} 
Portanto, a partir da consideração de Estado Socioambiental, a tarefa de assegurar bem-estar enfrenta um panorama mais extenso, em relação a deveres de defesa e prestação do Estado, porque expõe a intenção de garantir um mínimo existencial e isonomia nas relações socioambientais diante do princípio da não discriminação, de forma que o ambiente sadio e seus bens e recursos naturais devem poder ser fruídos de forma igual tanto entre as atuais quanto futuras gerações, cabendo tanto à comunidade nacional, quanto a internacional, a consecução do Estado de Direito social, democrático e ambiental ${ }^{39}$.

Em razão disso, Tiago Fensterseifer propõe no livro "Direitos fundamentais e proteção do ambiente: a dimensão ecológica da dignidade humana no marco jurídico-constitucional do Estado Socioambiental de Direito" a articulação das demandas sociais e o direito ao ambiente, relacionando de forma ordenada e conjunta a interdependência dos direitos fundamentais, a exemplo do direito à vida e saúde totalmente dependentes do ambiente, da boa qualidade do ar, da água, do solo, dos alimentos para o pleno desenvolvimento humano ${ }^{40}$.

Dessa forma, associar o direito à saúde, à alimentação e preservação da idoneidade ambiental, contribui e fortalece para garantir o mínimo existencial indispensável para sadia qualidade de vida e dignidade humana ${ }^{41}$.

A CRFB/88 assegurou o direito a saúde no rol dos Direitos Fundamentais sociais nos arts. $6^{\circ}, 196$ e $197^{42}$, como garantia à todos e dever do Estado de assegurá-lo, por meio de políticas públicas sociais e econômicas que visem à redução do risco de doenças e o acesso universal e igualitário às ações e serviços, bem como a Lei $n^{\circ} 8.080$ de 19.09 .1990 dispôs no art. $2^{\circ}$ que a saúde é um direito fundamental do ser humano, devendo o Estado prover as condições indispensáveis ao seu pleno exercício, reconhecendo desse modo a ampla dimensionalidade do dever do Estado de, para sua promoção, proteção e recuperação, abster-se de praticar atos que prejudiquem a sociedade, de implementar o direito social, e proteger o ambiente.

\footnotetext{
${ }^{39}$ AYALA, Patryck de Araújo. Direito Fundamental ao Ambiente e a Proibição de Regresso nos Níveis de Proteção Ambiental na Constituição Brasileira. In: FERREIRA, Heline Sivini; FERREIRA, Maria Leonor Paes Cavalcanti (Org.). Dano Ambiental na Sociedade de Risco. p. 110.

${ }^{40}$ FENSTERSEIFER, Tiago. Direitos Fundamentais e Proteção do Ambiente: a dimensão ecológica da dignidade humana no marco jurídico-constitucional do Estado Socioambiental de Direito. Porto Alegre: Livraria do Advogado Editora, 2008, p. 76.

${ }^{41}$ SILVA, Brisa Arnoud da Silva. A Importância do Mínimo Existencial Ecológico para a Concretização do Estado Democrático de Direito. Revista Justiça do Direito, v. 28, no 1, p. 84-107, jan./jun. 2014. Disponível em: <www.upf.br/seer/index.php/rjd/article/download/4832/3259>. Acesso em: 12 maio 2015.

${ }^{42}$ CRFB/88, Art. $6^{\circ}$. São direitos sociais a educação, a saúde, a alimentação, o trabalho, a moradia, o transporte, o lazer, a segurança, a previdência social, a proteção à maternidade e à infância, a assistência aos desamparados, na forma desta Constituição.

Art. 196. A saúde é direito de todos e dever do Estado, garantido mediante políticas sociais e econômicas que visem à redução do risco de doença e de outros agravos e ao acesso universal e igualitário às ações e serviços para sua promoção, proteção e recuperação.

Art. 197. São de relevância pública as ações e serviços de saúde, cabendo ao Poder Público dispor, nos termos da lei, sobre sua regulamentação, fiscalização e controle, devendo sua execução ser feita diretamente ou através de terceiros e, também, por pessoa física ou jurídica de direito privado.
} 
A alimentação adequada foi consagrada recentemente no rol dos Direitos Sociais por meio da Emenda Constitucional 64, de 2010, já preconizada pela Lei $n^{\circ}$ 11.346, de 15.11.2006, que criou o Sistema Nacional de Segurança Alimentar e Nutricional - SISAN com objetivo de assegurar o direito fundamental à alimentação adequada (art. $2^{\circ}$ da Lei $n^{\circ} 11.346 / 2006$ ), integrando a concepção do mínimo existencial indispensável à sadia qualidade de vida.

Porque a insegurança alimentar trata de um direito diretamente afetado pela degradação ambiental e à transformação dos modos de vida em sociedade. Os problemas de saúde não se limitam a dimensão biomédica, no sentido da garantia de medicamentos para a conservação da vida, mas se relacionam, sobretudo, à qualidade de vida, a cultura e violência ${ }^{43}$.

Falar em saúde implica levar em consideração a qualidade do ar que se respira, os reflexos do consumismo desenfreado ${ }^{44}$, a desnutrição a pobreza política $^{45}$, a degradação social, a degradação ambiental ${ }^{46}$, a desigualdade,

${ }^{43}$ LESSA, Daniela. Mapa mostra como a injustiça ambiental afeta a saúde coletiva no país. FIOCRUZ - Fundação Osvaldo Cruz: uma instituição à serviço da vida. Disponível em: $<$ http://portal.fiocruz.br/pt-br/content/injusti\%C3\%A7a-ambiental-afeta-sa\%C3\%BAde-coletiva> . Acesso em: 23 jan. 2015.

${ }_{44}$ BAUMAN, Zygmunt. Vida para Consumo: a transformação das pessoas em mercadoria. Tradução Carlos Alberto Medeiros. Rio de Janeiro: Zahar, 2008, p. 65: "Além de ser um excesso e um desperdício econômico, o consumismo também é, por essa razão, uma economia do engano. Ele aposta na irracionalidade dos consumidores, e não em suas estimativas sóbrias e bem informadas; estimula emoções consumistas e não cultiva a razão. Tal como ocorre com o excesso e o desperdício, o engano não é um sinal de problema na economia de consumo. Pelo contrário, é sintoma de sua boa saúde e de que está firme sobre os trilhos".

${ }^{45}$ DEMO, Pedro. Direitos Humanos e Educação: pobreza política como desafio central. Brasília: UNB, 1999. Disponível em: <http://www.dhnet.org.br/educar/textos/demo_direitos_humanos_e_ educacao.pdf>. Acesso em: 24 out. 2014: "A face política da pobreza aparece em seu caráter excludente. No fenômeno da exclusão social a substância mais característica é política, não propriamente ou apenas econômica, já que, mais do que não ter, está em jogo não ser. A exclusão mais comprometedora não é aquela ligada ao acesso precário a bens materiais, mas aquela incrustada na repressão do sujeito, tendo como resultado mais deletério a subalternidade. O nível mais profundo de pobreza política é, assim, a condição de ignorância: o pobre sequer consegue saber e é coibido de saber que é pobre. Por conta disso, atribui sua pobreza a fatores externos, eventuais ou fortuitos, sem perceber que pobreza é processo histórico produzido, mantido e cultivado. Não chega à ideia crucial de que, para sair da pobreza, é mister, primeiro, compreender que se trata de injustiça e de imposição social, e, segundo, de desenhar projeto próprio de solução, no qual a peça fundamental seja o próprio pobre".

${ }^{46}$ A Política Nacional de Meio Ambiente, Lei $n^{\circ} 6.938 / 81$, conceitua degradação ambiental, no artigo $3^{\circ}$, inciso II, como: "alteração adversa das características do meio ambiente". Segundo José Rubens Morato Leite a compreensão de degradação ambiental deve ser feita conjuntamente com a de poluição, em que associa a poluição em virtude da degradação ambiental. Nestes termos, o art. $3^{\circ}$, inc. III, da Lei $n^{\circ} 6.938 / 81$ define: III - poluição, degradação da qualidade ambiental resultante de atividades que direta ou indiretamente: a) prejudiquem a saúde, a segurança e o bem-estar da população; b) criem condições adversas às atividades sociais e econômicas; c) afetem desfavoravelmente a biota; d) afetem as condições estéticas e sanitárias do ambiente; e) e lancem matérias e energias em desacordo com os padrões ambientais estabelecidos. LEITE, José Rubens Morato. Dano Ambiental: do individual ao coletivo extrapatrimonial. São Paulo: Revista dos Tribunais, 2000. p. 105. 
ou seja, como, manifestamente, as interferências na qualidade ambiental refletem diretamente na dimensão social e na qualidade de vida ${ }^{47}$.

Essa inter-relação entre os direitos fundamentais demonstra o vínculo essencial que existe entre vida e ambiente, saúde e ambiente, segurança e ambiente, que permite articular e configurar os instrumentos jurídicos para um melhor enfrentamento da crise socioambiental ${ }^{48}$.

A crise socioambiental tem um maior ou menor impacto conforme a capacidade da sociedade reagir e a iniciativa do Estado de redefinir padrões de responsabilidade, segurança, controle e limitação do dano ${ }^{49}$.

E a responsabilidade da pessoa jurídica é levantada justamente pela necessidade de controle dos sistemas, em virtude de que grande parte das empresas são responsáveis pelo desencadeamento da Sociedade de Risco, e dessa forma, a tutela penal ambiental criminaliza as condutas lesivas ao ambiente, já prevista no art. $225, \S 3^{\circ}$ da CRFB/88, regulamentada pela Lei própria de Crimes Ambientais ${ }^{50}$, que admite a responsabilidade penal da pessoa jurídica aludindo a responsabilidade social ${ }^{51}$, em que o juízo de culpabilidade configura-se em comparação com outras empresas do mesmo porte e em situação paralela ${ }^{52}$.

O Estado também é imputável por danos socioambientais ${ }^{53}$, no que procura-se definir a responsabilidade extracontratual do Estado como dever de reparar os prejuízos causados a terceiros, imputáveis em virtude de

\footnotetext{
${ }^{47}$ BRASIL. Secretaria de Educação Fundamental. Parâmetros Curriculares Nacionais: apresentação dos temas transversais, ética. Brasília: MEC/SEF, 1997, p. 27. Disponível em: <http://portal.mec. gov.br/seb/arquivos/pdf/livro081.pdf>. Acesso em: 23 jan. 2015.

${ }_{48}$ BENJAMIN, Antônio Herman. Constitucionalização do Ambiente e a Ecologização da Constituição Brasileira. In: CANOTILHO, José Joaquim Gomes; LEITE, José Rubens Morato (orgs.). Direito Constitucional Ambiental Brasileiro. São Paulo: Saraiva, 2007. p. 92.

$49 \mathrm{JACOBI}$, Pedro. Educar na Sociedade de Risco: o desafio de construir alternativas. Faculdade de Educação da USP e PROCAM-USP. Revista em Educação Ambiental, v. 2, nº 2, p. 49-65, 2007. Disponível em: <http://www.revistas.usp.br/pea/article/view/30029>. Acesso em: 06 dez. 2014. p. 57-62.

${ }^{50}$ A Lei no 9.605 de 12.02.1998.

${ }^{51}$ CRUZ, Ana Paula Fernandes Nogueira da. Culpabilidade e a Responsabilidade Criminal da Pessoa Jurídica. Revista de Direito Ambiental, v. 9, n 35, p. 123-154. jul./set. São Paulo: Revista dos Tribunais, 2004, p. 140; MUKAI, Toshio. A Responsabilidade Civil e Penal no Campo do Direito Ambiental. In: SILVA, Bruno Campos da (Org.). Direito Ambiental: enfoques variados. São Paulo: Lemos \& Cruz, 2004, p. 426; Leite e Bello Filho, Direito Ambiental contemporâneo. São Paulo: Manole, 2004, p. 159.

52 Do Estado Liberal para Socioambiental de Direito: o caminho para o desenvolvimento sustentável. In: SOUZA, Maria Claudia da Silva Antunes de; ARMADA, Charles Alexandre Souza (Org.). Teoria Jurídica e Transnacionalidade, vol. II, p. 129-152. Disponível em: <http://www.univali.br/ ppcj/ebook>. Acesso em: 21 jul. 2014.

${ }^{53}$ SILVA, Brisa Arnoud da Silva; RONCONI, Elizangela Pieta. Em Busca da Superação do Complexo de Vira-lata: o fortalecimento do Estado Socioambiental no espaço transnacional. In: GARCIA, Denise Schmidtt Siqueira. Debates Sustentáveis: análise multidimensional e governança ambiental. p. 31-53. Itajaí: UNIVALI, 2015. Disponível em: <http://www.univali.br/ppcj/ebook>. Acesso em: 20 maio 2015.
} 
comportamentos unilaterais, lícitos ou ilícitos, comissivos ou omissivos, materiais ou jurídicos, decorrente de ato administrativo, legislativo e judicial ${ }^{54}$.

Três teses da doutrina do Direito Público respaldam a obrigação do Estado de responder por suas ações e omissões, e o art. 37 , § $6^{\circ}$ da CRFB/88 adota a teoria da Risco administrativo, que fundamenta a responsabilidade objetiva, aliada ao $225, \S 3^{\circ}$ e art. $14, \S 1^{\circ}$ da Lei $n^{\circ} 6.938 / 81$, e dessa forma, os prejuízos advindos do comportamento estatal, ou pela falta dele, contra o ambiente e a população, analisado a partir das duas faces do princípio da proporcionalidade, seja pela proibição de excesso ou proibição de insuficiência, tornam legitima a reivindicação por correção e reparação desse dano ${ }^{55}$.

Constata-se que, tanto nos casos de empreendimentos como em desastres ecológicos, a omissão na fiscalização e no controle de danos ambientais, e a falta de tomada de providências por parte do Poder Público são os principais motivos da contínua degradação ambiental, que por consequência atinge a vulnerabilidade socia ${ }^{56}$.

Assim, a responsabilização extracontratual do Estado, a responsabilidade penal da pessoa jurídica, o direito à saúde, direito à alimentação e o princípio do mínimo existencial ecológico, o direito ao/do/sobre o ambiente, admitidos na evolução do Estado Socioambiental de Direito, são encadeados como mecanismos que podem contribuir no combate de conflitos socioambientais, sobretudo diante do compromisso de pôr em prática as concepções do princípio sustentabilidade homeostática e o desenvolvimento sustentável ${ }^{57}$.

\section{O DIREITO ESSENCIAL À INFORMAÇÃO E À PARTICIPAÇÃO PARA O CONTROLE SOCIAL}

Nesse momento tratar-se-ão dos direitos à informação, à participação, 0 controle social e o Movimento da Justiça Ambiental buscando esclarecer que a reação para a mudança, que se pretende a partir da reflexão, é hipotética, mas somente pode e poderá ser possível com a cumulação dessas garantias, e a capacidade da sociedade se organizar, se mobilizar e interagir com movimentos de representação social, empresas e Poder Público.

Todos têm o direito de acesso à informação e essa é uma garantia convencionada em diversos diplomas legais. Entretanto, os poderes que dominam a sociedade, os interesses econômicos, manipulam a informação e a forma de percepção da realidade, e, na prática, os sujeitos - homem-comum - não refletem na vida cotidiana sobre os efeitos reflexos das ações e na

\footnotetext{
${ }^{54}$ CUNHA JUNIOR, Dirley da. Curso de Direito Administrativo. Salvador: Juspodivm, 2015. p. 323-347.

${ }^{55}$ FENSTERSEIFER, Tiago. Direitos Fundamentais e Proteção do Ambiente: a dimensão ecológica da dignidade humana no marco jurídico-constitucional do Estado Socioambiental de Direito. Porto Alegre: Livraria do Advogado Editora, 2008, p. 287-288.

${ }^{56}$ BIANCHI, Patrícia Nunes Lima. Eficácia das Normas Ambientais. São Paulo: Saraiva, 2010. p. 147.

${ }^{57}$ FREITAS, Juarez. Sustentabilidade: direito ao futuro. Belo Horizonte: Editora Fórum, 2011. p. 32; p. 40.
} 
inter-relação dos riscos na Sociedade ${ }^{58}$ de Consumo $^{59}$ e Informação ${ }^{60}$. Basicamente o entendimento da informação como instrumento de controle social esbarra na tentações estimuladas pelas políticas desenvolvimentistas de governo ${ }^{61}$.

Dessa forma, a necessidade de transparência e visibilidade das ações perpassa à seara pública, entrelaçando os direitos à informação pública e ambiental na Sociedade de Risco, Consumo e da Informação.

A CRFB/88, ao consagrar o regime democrático assegurou o direito à informação e comprometeu-se com a publicidade e transparência nos arts. $5^{\circ}$ e 37. Ao estabelecer o direito ao ambiente estipulou no parágrafo $1^{\circ}$, do art. 225 a publicidade da informação ambiental como instrumento de efetivação desse direito. A conjugação desses institutos institui o direito fundamental à informação ambiental, e com isso se prepara a possibilidade de controle social sobre a gestão pública e tudo que diz respeito ao ambiente e que reflete em nós.

Ambas, Declaração do Rio de Janeiro de 1992, especificamente no Princípio $10^{62}$, e a Convenção de Aarhus ${ }^{63}$, considerada um marco para a

58 SILVA, Brisa Arnoud da. A Sociedade da Informação a Favor da Democracia: o direito da informação e livre escolha no consumo de alimentos transgênicos. Publicatio - UEPG: Ciências Sociais Aplicadas, Ponta Grossa, 23 (1): p. 103-120, jan./jun. 2015, p. 106-106. Disponível em: <http://www.revistas2.uepg.br/index.php/sociais/article/view/7158/4623>. Acesso em: 07 nov. 2015.

59 BAUMAN, Zygmunt. Vida para Consumo: a transformação das pessoas em mercadoria. Tradução Carlos Alberto Medeiros. Rio de Janeiro: Zahar, 2008, p. 63: "A sociedade de consumo tem como base de suas alegações a promessa de satisfazer os desejos humanos em um grau que nenhuma sociedade do passado pôde alcançar, ou mesmo sonhar, mas a promessa de satisfação só permanece sedutora enquanto o desejo continua insatisfeito; mais importante ainda, quando o cliente não está 'plenamente satisfeito' - ou seja, enquanto não se acredita que os desejos que motivaram e colocaram em movimento a busca da satisfação e estimularam experimentos consumistas tenham sido verdadeira e totalmente realizados".

${ }^{60}$ A Sociedade da Informação, também chamada de revolução da informação, era da informação, infoera, sociedade em rede, revolução digital, cibersociedade, é termo atribuído a esse cenário que canaliza e aprimora os meios de comunicação e possibilita a interação coletivizada da informação. A categoria Sociedade da Informação abrange toda a dinâmica de acessar-reunirorganizar-distribuir, para facilitar o acesso à informação, e o avanço e agilidade dos meios de telecomunicação e microeletrônica, como a internet, o satélite, a telefonia celular e a rede de fibra óptica, vem transformando as relações sociais, culturais, políticas, econômicas, jurídicas, globalizadas. Essas tecnologias, por si só, não transformam a sociedade, mas a maneira como são utilizadas pelas pessoas repercutem as mudanças da Sociedade da Informação. FIORILLO, Celso Antonio Pacheco. Fundamentos Constitucionais do Meio @mbiente Digit@L na Sociedade da Informação. In: PAESANI, Liliana. O Direito na Sociedade da Informação III: A evolução do direito digital, v. 3, Atlas, 2013. VitalBook file. Minha Biblioteca. Disponível em: <http://online. minhabiblioteca.com.br/books/9788522482139>. Acesso em: 09 set. 2014. p. 13.

61 BAUMAN, Zygmunt. Vida para Consumo: a transformação das pessoas em mercadoria. Tradução Carlos Alberto Medeiros. Rio de Janeiro: Zahar, 2008, p. 55-57.

${ }^{62}$ Princípio 10 - O melhor modo de tratar as questões ambientais é com a participação de todos os cidadãos interessados, em vários níveis. No plano nacional, toda pessoa deverá ter acesso adequado à informação sobre o ambiente de que dispõem as autoridades públicas, incluída a informação sobre os materiais e as atividades que oferecem perigo em suas comunidades, assim como a oportunidade de participar dos processos de adoção de decisões. Os Estados deverão facilitar e fomentar a sensibilização e a participação do público, colocando a informação à 
democracia ambiental mundial, inter-relacionam os direitos da informação, da participação e acesso à justiça para a materialização da eco cidadania.

A Convenção de Aarhus destina-se a resguardar e fortalecer direitos de participação, de informação e procedimentais em matéria ambiental, para envolver o público na tomada de decisão em questões ambientais, de tal modo que não garantir tais direitos, implica violação de uma obrigação internacional pelas Partes da Convenção ${ }^{64}$.

Dessa maneira, sob a ótica de instrumentalidade, o direito à informação, a publicidade e transparência constituem pressuposto para a participação e controle social.

A participação popular, mais que um direito, é um dever de cidadania ${ }^{65}$. A obrigação cidadã de participar corresponde ao dever estatal de garantir o acesso à essa participação, e a CRFB/88, ao assumir a concepção de Estado Democrático Socioambiental de Direito, muniu o povo de instrumentos jurídicos aptos à essa defesa.

No sistema constitucional brasileiro, tal participação faz-se de várias maneiras diferentes. A primeira delas consubstancia-se no dever jurídico de proteger e preservar o meio ambiente; a segunda, no direito de opinar sobre as políticas públicas através da participação em audiências públicas, integrando órgãos colegiados, etc. Há, ainda, a participação que ocorre através da utilização de mecanismos judiciais e administrativos de controle dos diferentes atos praticados pelo Executivo, tais como as ações populares, as representações e outros. Não se pode olvidar, também, das iniciativas legislativas, que podem ser patrocinadas pelos cidadãos. A materialização do princípio democrático faz-se através de diversos instrumentos processuais e procedimentais ${ }^{66}$.

O controle social é definido como uma garantia conquistada no paradigma democrático ${ }^{67}$, que permite a participação popular no controle, fiscalização,

disposição de todos. Deverá ser proporcionado acesso efetivo aos procedimentos judiciais e administrativos, entre os quais o ressarcimento de danos e os recursos pertinentes. Disponível em: <http://veja.abril.com.br/complementos-materias/rio+20-widgets/pdf/declaracao-do-rio-de-janeirosobre-meio-ambiente-desenvolvimento.pdf>. Acesso em: 04 out. 2014.

${ }^{63}$ A Convenção de Aarhus sobre Acesso à Informação, Participação do Público no Processo de Tomada de Decisão e Acesso à Justiça em Matéria de Ambiental, adotada em 25.6.1998, durante a $4^{a}$ Conferência Ministerial "Ambiente para a Europa", entrou em vigor em 30.10.2001 e é considerada um marco no desenvolvimento procedimental do Direito Ambiental e na expansão da noção de democracia para uma aberta e transparente sociedade. Disponível em: <www.unece.org/ fileadmin/DAM/env/pp/EUtexts/conventioninportogese.pdf>. Acesso em: 15 maio 2015.

${ }^{64}$ EBBESSON, Jonas. "Acesso à Informação, Participação Pública e Acesso à Justiça em Matéria Ambiental: uma breve introdução à Convenção de Aarhus". Revista de Direito Ambiental, ano 16, no 64. p. 31, out./dez. 2011.

${ }^{65}$ SÉGUIN, Élida. Direito Ambiental: nossa casa planetária. Rio de Janeiro: Forense, 2006, p. 321.

${ }^{66}$ ANTUNES, Paulo de Bessa. Direito Ambiental. 7. ed., Rio de Janeiro: Lumen Juris, 2004. p. 35.

${ }^{67}$ MILESKI, Hélio Saul. Controle Social: um aliado do controle oficial. Interesse Público, ano 8, $n^{\circ} 36$, mar./abr. 2006, Porto Alegre: Notadez, p. 85-98, p. 89. 
e monitoramento das ações públicas ${ }^{68}$. A participação da sociedade na gestão pública pode ocorrer de diferentes maneiras, de forma oficial e não-oficial ${ }^{69}$. Trata-se de participação oficial quando envolve órgão ou entidade pública e refere-se a utilizar instrumentos garantidos à defesa, à disposição na CRFB/88 e em legislação infraconstitucional ${ }^{70}$.

A participação não-oficial caracteriza-se, basicamente, pela ausência de uma formalidade específica. É desvinculada de órgãos públicos e todos os caminhos legalmente permitidos são válidos, como a mobilização da opinião pública, o direito de reunião (notadamente para fins pacíficos, conforme o art. 50, inc. XVIII, CRFB/88), a formação de grupos de pressão e ativismo, construindo caminhos de resistência em rede. Os grupos de pressão não almejam poder, propriamente dito, mas intencionam, sobretudo, influenciá-lo no sentido do atendimento de interesses e reivindicações comuns, e podem dificultar, e mesmo, inviabilizar determinadas decisões tomadas unicamente com objetivo de manutenção e estoque de controle e prestígio político ${ }^{71}$.

(...) um povo participante é aquele que exerce a cidadania num regime jurídico em que o Estado zela não apenas pelos seus direitos de cidadania, mas também pelos direitos humanos. A participação política do povo se dá pelo plebiscito, referendo e pela iniciativa popular na elaboração de leis, mas também exerce a sua participação numa democracia viva através de formas autônomas, graças ao resguardo estatal dos direitos humanos e de cidadania, garantindo, inclusive, que o povo possa ser considerado como ator informal da luta política, por do reconhecimento de movimentos e associações que estabelecem uma resistência aos efeitos deletérios da globalização, questionado através de uma rede global de mobilização popular determinadas tomadas de decisão política, que podem comprometer os interesses desse mesmo povo ${ }^{72}$.

Importante analisar, também, o auxílio das ONGs e movimentos de representação no combate de causas como a discriminação e injustiça ambiental. As ONGs são uma importante forma de representação popular no mundo e têm papel vital na cooperação em causas ambientais, de assistência humanitária, com pessoal especializado, informação, voz para os povos sem representação, além da fiscalização do cumprimento de tratados

\footnotetext{
${ }^{68}$ BASTOS, Frederico Silva. Controle Social da Administração Financeira do Estado: democracia, transparência e responsabilidade. Revista dos Tribunais, ano 2012, vol. 936, out. 2013.

${ }^{69}$ SÉGUIN, Élida. Direito Ambiental: nossa casa planetária. Rio de Janeiro: Forense, 2006, p. 321.

${ }^{70}$ SÉGUIN, Élida. Direito Ambiental: nossa casa planetária. Rio de Janeiro: Forense, 2006, p. 321-363.

${ }^{71}$ SÉGUIN, Élida. Direito Ambiental: nossa casa planetária. Rio de Janeiro: Forense, 2006, p. 323.

72 ALVES, Fernando Antonio. O Ativismo Popular nas Redes Sociais pela Internet e o Marco Constitucional da Multidão, no Estado Democrático de Direito: uma discussão prévia sobre participação popular e liberdade de expressão no Brasil, pós-manifestações de junho de 2013. REDESG - Revista Direitos Emergentes na Sociedade Global, v. 3, $\mathrm{n}^{\circ}$ 1, jan./jun. 2014, p. 16-49, p. 24. Disponível em: <http://cascavel.ufsm.br/revistas/ojs-2.2.2/index.php/REDESG/article/view/ 14478/pdf\#.VgnKNvlViko>. Acesso em: 29 set. 2015.
} 
e legislações ${ }^{73}$. Os movimentos de representação desempenham essencial papel, a exemplo do Movimento da Justiça Ambiental, no combate à injustiça ambiental $^{74}$ e se manifesta a partir da percepção de que existem grupos da sociedade civil que, por que são mais vulneráveis, são os mais expostos aos riscos e prejuízos ambientais. O Ecologismo dos Pobres é o movimento que envolve a luta por justiça social relacionada a própria sobrevivência, com objetivos definidos em termos de necessidades ecológicas para a vida, como energia (também entendido como alimentação), água, espaço para morar, uma luta por ecojustiça ${ }^{75}$.

No Brasil, o Movimento de Justiça Ambiental ampara desde $2001^{76}$ a defesa dos direitos de comunidades tradicionais; os direitos de proteção ambiental equânime, contra a segregação e desigualdade socioambiental; os direitos de acesso igualitário aos recursos ambientais; e em si, os direitos das futuras gerações, porque enquanto os prejuízos ambientais puderem ser empurrados para as comunidades mais vulneráveis, com menos poder de reação, a degradação ambiental tende a continuar ${ }^{77}$.

Também é importante enfatizar o auxílio e relevância dos movimentos locais de representação social, a exemplo da experiência do "abraço" na região do Canto do Morcego, organizado pelo o Movimento "Não deixe o encanto do morcego acabar" e pela União dos Amigos da Praia Brava - UNIBRAVA, que são movimentos de representação social local da cidade de Itajaí-Santa Catarina, que auxiliam na luta e na pressão não apenas pela preservação do Canto do Morcego (no lado norte da Praia Brava, em Itajaí), mas sobretudo com a conscientização dessa comunidade da importância da qualidade do ambiente para a qualidade de vida ${ }^{78}$.

\footnotetext{
${ }^{73}$ VIEIRA, Liszt. Os Argonautas da Cidadania: a sociedade civil na globalização. Rio de Janeiro: Editora Record, 2001, p. 125.

${ }^{74}$ ACSELRAD, Henri; MELLO, Cecília Campello de Amaral; BEZERRA, Gustavo das Neves. O que é Justiça Ambiental. Rio de Janeiro: Garamond, 2008. p. 40-41: "Definiu-se então por injustiça ambiental o mecanismo pelo qual sociedades desiguais, do ponto de vista econômico e social, destinam a maior carga dos danos ambientais do desenvolvimento às populações de baixa renda, aos grupos raciais discriminados, aos povos étnicos tradicionais, aos bairros operários, às populações marginalizadas e vulneráveis".

${ }^{75}$ ALIER, Joan Martinez. Ecologismo dos Pobres: conflitos ambientais e linguagens de valoração. São Paulo: Contexto, 2007. p. 351.

${ }^{76}$ ACSELRAD, Henri. Justiça Ambiental e a Construção Social do Risco. Disponível em: <http://ojs.c3sl.ufpr.br/ojs2/index.php/made/article/viewFile/22116/14480>. Acesso em: 04 abr. 2013.

77 ACSELRAD, Henri. A Ambientalização das Lutas Sociais: o caso do movimento por justiça ambiental. Disponível em: <http://www.scielo.br/pdf/ea/v23n68/10.pdf>. Acesso em: 21 jul. 2014.

${ }^{78}$ O Sol Diário. Abraço ao Canto do Morcego reúne centenas de pessoas em Itajaí. Publicado em: 24 ago. 2014. Disponível em: <http://osoldiario.clicrbs.com.br/sc/noticia/2014/08/abraco-ao-cantodo-morcego-reune-centenas-de-pessoas-em-itajai-4582413.html>. Acesso em: 19 maio 2015; Notícias do Dia. Justiça proíbe construções no Canto do Morcego, em Itajaí. Publicado em: 02 out. 2014. Disponível em: <http://ndonline.com.br/vale/noticias/202448-justica-proibe-construcoes-no-cantodo-morcego-em-itajai.html>. Acesso em: 19 maio 2015; Redação Band SC. Gravação do quadro 'Proteste Já' do programa CQC em prol da Estrada da Rainha. Publicado em: 22 maio 2014. Disponível em: <http://www.bandsc.com.br/canais/materia-view.html?id=15824>. Acesso em: 19 maio 2015.
} 


\section{A PROPOSTA DA ECO CIDADANIA}

Assim, da nossa interação com o meio, sucedem efeitos cujas implicações retroagem sobre toda a coletividade. A percepção dos efeitos reflexos da modernidade reflexiva da Sociedade de Risco no nosso próprio cotidiano obriga-nos a refletir sobre a necessidade de redirecionar as condutas humanas para a garantia da nossa própria sobrevivência, "A solução revolucionária que o mundo vinha buscando desesperadamente, foi substituída pela conscientização da natureza insustentável do então estilo de vida e do padrão de consumo" "79

Dessa forma, associar instrumentos jurídicos contribui na luta pela proteção do ambiente essencial à sadia qualidade de vida e dignidade de todos, tendo em vista a inegável necessidade de informar e instrumentalizar a Sociedade de Risco, de forma integrada, preventiva, precaucional e solidária, tendo em vista o surgimento dos novos e complexos riscos da sociedade pós-moderna.

Diante do reconhecimento constitucional do direito ao ambiente, impondo atuação conjunta do Poder Público e da coletividade para sua defesa e preservação, evidenciou-se que a propagação de informação e conhecimento é instrumento imprescindível à participação da sociedade para assegurar a efetividade desse direito, para ampliar o envolvimento com as causas ambientais, na sua defesa e respeito da legislação ambiental.

Não obstante, ter consciência de que problemas humanos são complexos e que estão envolvidos na mesma teia da vida permite perceber como as adversidades ambientais estão relacionadas às adversidades sociais. Compreender a complexidade ambiental e assimilar que quando pensamos o todo estamos incluídos e determinados por esse ${ }^{80}$, que não existe o micro sem macro e vice-versa, permite enfrentar os impactos derivados de certas ações e comportamentos humanos em relação ao meio manifestando solidariedade e respeito as lutas com interesse comum, assumindo o compromisso de transformação do atual paradigma desenvolvimentista pela perspectiva da eco cidadania.

O conceito de cidadania surgiu na Idade Média, e referia-se às pessoas que viviam nas cidades e que reclamavam sua liberdade e seus direitos, em oposição à condição de servidão que existiu por séculos no campo. Posteriormente, quando o Estado-nação substituiu a cidade-Estado, a cidadania passou a referir-se, desse modo, à relação entre Estado e cidadão, especialmente no tocante a direitos e obrigações ${ }^{81}$. Hoje, com o alcance da

\footnotetext{
${ }^{79}$ PAULI, Gunter. Emissão Zero - a busca por novos paradigmas: o que os negócios podem oferecer à sociedade? Tradução José Wagner Maciel Kaehler; Maria Tereza Raya Rodriguez. Porto Alegre: EDIPUCRS, 1996, p. 27.

${ }^{80}$ BOFF, Leonardo. A Águia e a Galinha: uma metáfora da condição humana. 32. ed., Petrópolis, RJ: Editora Vozes, 1999, p. 72.

${ }^{81}$ PAULI, Gunter. Emissão Zero - a busca por novos paradigmas: o que os negócios podem oferecer à sociedade? Tradução José Wagner Maciel Kaehler; Maria Tereza Raya Rodriguez. Porto Alegre: EDIPUCRS, 1996, p. 19.
} 
sociedade globalizada, esse conceito de cidadania é considerado defasado, uma vez que não pode mais ser visto unicamente como conjunto de direitos formais nos limites territoriais do Estado, e é essencial um modo de incorporação de indivíduos e grupos ao contexto social ${ }^{82}$. A partir dessa concepção constrói-se o conceito de cidadania universal, aqui entendida como aptidão para exercer direitos, aspirando à harmonização das obrigações universais e particulares através de uma visão comum da condição humana ${ }^{83}$ : "Pode-se afirmar que a universalização dos direitos humanos inovou o tema da cidadania ao reconhecer o homem como sujeito de direitos fundamentais, sem qualquer referência a sua nacionalidade" ${ }^{\prime 84}$. Estendendo a definição de cidadania à povo, vincula-se à concepção de democracia, não apenas como destinatário das ações do Estado, mas sobretudo como ator político participante, que exerce a cidadania num regime jurídico em que o Estado zela pelos seus direitos de cidadania e direitos humanos ${ }^{85}$. Entretanto, longe de favorecer a cidadania e a democracia viva, o assombroso cenário de "barricadas da fortaleza Europa" ${ }^{86}$ evidenciadas pelas construções de cercas e muros fronteiriços para conter o fluxo migratório, o endurecimento das condições de acolhida aos imigrantes, a criação de centros de triagem para os refugiados, e a aceleração das expulsões daqueles que não obtiveram o asilo, são barreiras físicas e jurídicas que revelam outra faceta do estado de crise generalizada, reagindo, definitivamente, em cadeia, com manifesto distanciamento do ideal versus real na segurança e resguardo dos direitos humanos, direitos fundamentais, no contexto do direito dos refugiados na Europa ${ }^{87}$. Infelizmente essa realidade de dificuldades e empecilhos não é uma situação tão distante do Brasil, que recebe muitos imigrantes que também enfrentam opressão e

\footnotetext{
${ }^{82}$ VIEIRA, Liszt. Os Argonautas da Cidadania: a sociedade civil na globalização. Rio de Janeiro: Editora Record, 2001, p. 221.

${ }^{83}$ VIOLA, Eduardo; LEIS, Héctor R. Mudanças na Direção de uma Globalização Multidimensional Complexa. Cadernos de Pesquisa Interdisciplinar em Ciências Humanas, $n^{\circ}$ 40, nov. 2002. p. 11. Disponível em: <https://periodicos.ufsc.br/index.php/cadernosdepesquisa/article/view/1112>. Acesso em: 06 out. 2015.

${ }^{84}$ MAGNO, Patricia. Refugiado, Cidadão Universal: uma análise do direito à identidade pessoal. Lugar Comum, $\mathrm{n}^{\circ}$ 27, p. 185-225, p. 190. Disponível em: <http://uninomade.net/wp-content/files $\mathrm{mf} / 110810120851$ Refugiado\%20Cidadao\%20Universal\%20uma\%20analise\%20do\%20direito\%20a \%20identidade\%20pessoal\%20-\%20Patricia\%20Magno.pdf>. Acesso em: 27 set. 2015.

${ }^{85}$ ALVES, Fernando Antonio. O Ativismo Popular nas Redes Sociais pela Internet e o Marco Constitucional da Multidão, no Estado Democrático de Direito: uma discussão prévia sobre participação popular e liberdade de expressão no Brasil, pós-manifestações de junho de 2013. REDESG - Revista Direitos Emergentes na Sociedade Global, v. 3, no 1, jan./jun. 2014, p. 16-49. Disponível em: <http://cascavel.ufsm.br/revistas/ojs-2.2.2/index.php/REDESG/article/view/14478/ pdf\#.VgnKNvlViko>. Acesso em: 29 set. 2015, p. 24.

${ }^{86}$ RTP Notícias. Amnistia Internacional denuncia "barricadas da fortaleza Europa" face aos refugiados sírios. Disponível em: <http://www.rtp.pt/noticias/mundo/amnistia-internacional-denunciabarricadas-da-fortaleza-europa-face-aos-refugiados-sirios_n703074>. Acesso em: 17 set. 2015.

${ }^{87}$ LEVY, Rafael Vivan. Não. Não Existe uma Crise Migratória na Europa! E por que devemos parar de usar esse termo. Observatório 9474. Disponível em: <https://observatorio9474. wordpress.com/2015/09/10/nao-nao-existe-uma-crise-migratoria-na-europa-e-por-que-devemos-pararde-usar-esse-termo/>. Acesso em: 01 nov. 2015.
} 
preconceito $^{88}$, que denota essa situação de desamparo, desrespeito e violência à dignidade humana ${ }^{89}$.

Assim, abrindo-se para a realidade de sentidos em permanente estado de multiplicação ${ }^{90}$, no momento histórico-cultural que vivemos, urge o respeito pelo outro e a consciência ética entre viventes, "Ético significa, portanto, tudo aquilo que ajuda a tornar melhor o ambiente para que seja uma moradia saudável: materialmente sustentável, psicologicamente integrada e espiritualmente fecunda" ${ }^{\prime \prime}$.

No que tratamos do ambiente complexo, é preciso ter em conta que o modelo capitalista está levando o planeta e os seres vivos à situação catastrófica do ponto de vista das condições de sobrevivência da vida humana e da vida em geral $^{92}$.

Desencadeiam-se na Sociedade de Risco desastres de proporções incalculáveis e os sinais disso já são visíveis, dentre tantos lamentáveis exemplos, o atual estado de calamidade no Rio Grande do Sul e Santa Catarina produzidos por tempestades que já assolaram grande parte dos Estados ${ }^{93}$, advindas de interferências na qualidade ambiental, que manifestamente, refletem na dimensão social e na qualidade de vida.

Por isso é importante construir a inter-relação entre as lutas sociais e ambientais, pois elas tendem a concordar, unidas ao redor de objetivos comuns. A vinculação do homem ao meio em que está contextualizado deve levar em conta as desigualdades individuais e, consequentemente, vincular os direitos humanos, sociais e ao ambiente, para garantir seus direitos de participação na sociedade, no exercício da eco cidadania, na luta pela preservação e sobrevivência ${ }^{94}$.

\footnotetext{
${ }^{88}$ FANTÁSTICO, G1. Milhares de estrangeiros buscam oportunidades no Brasil. Disponível em: http://g1.globo.com/fantastico/videos/t/edicoes/v/milhares-de-estrangeiros-buscam-oportunidadesno-brasil/3570062/. Acesso em: 20 out. 2015.

${ }^{89}$ Diário de Santa Maria, Grupo RBS. Senegalês tem o corpo queimado enquanto dormia em Santa Maria. Três homens jogaram fogo no colchão do imigrante, que teve queimaduras superficiais nas duas pernas. Disponível em: <http://diariodesantamaria.clicrbs.com.br/rs/geral-policia/noticia/ 2015/09/senegales-tem-o-corpo-queimado-enquanto-dormia-em-santa-maria-4846594.html>. Acesso em: 20 out. 2015.

${ }^{90}$ WARAT, Luis Alberto. Por quien cantan las Sirenas: Informe sobre Eco-ciudadania, Género y Derecho - Incidencias del barroco en el pensamento jurídico. Florianópolis: UNOESC/CPGD-UFSC, 1996, p. 20.

${ }^{91}$ BOFF, Leonardo. A Águia e a Galinha: uma metáfora da condição humana. 32. ed., Petrópolis, RJ: Editora Vozes, 1999, p. 90.

${ }^{92}$ LÖWY, Michael. Ecologia e Socialismo. Brasil de Fato: uma visão popular do Brasil e do mundo. Disponível em: <http://www.brasildefato.com.br/node/4023>. Acesso em: 07 out. 2015.

${ }_{93}$ G1 RS. Guaíba registra a segunda maior cheia da história no RS, 17 out. 2015. Disponível em: <http://g1.globo.com/rs/rio-grande-do-sul/noticia/2015/10/nivel-do-guaiba-atinge-recorde-e-mantemestado-de-alerta-no-rs.html>. Acesso em: 25 out. 2015.

${ }^{94}$ SEGUIN, Élida. Vitimização Ambiental. Disponível em: <http://www.arnaudeaguiar.com.br/2016/ index.php?option $=$ com_content\&view=article\&id=331:vitimizacao-ambiental\&catid $=50 \&$ Itemid $=427 \&$ lang=pt>. Acesso em: 26 mar. 2015.
} 
O paradigma da cidadania ecológica denota o caráter de responsabilidade para com o futuro da humanidade, e por isso mesmo precisa da participação ativa e efetiva, de cada um e de todos, na busca por uma sociedade melhor ${ }^{95}$.

A eco cidadania expressa o vínculo entre homens, a natureza e a sociedade, propondo uma resposta emancipatória e sustentável à modernização reflexiva, baseada na articulação e transformações que precisam ser efetuadas para garantir nosso direito ao futuro, envolvendo o homem na preservação da vida em todas as suas formas e na supressão dessa modelo de sociedade de tendência destrutiva e egoísta ${ }^{96}$.

A manifestação da eco cidadania como uma luta pelo direito ao futuro não se apresenta como resposta súbita, mas resulta da revolução e evolução de ideias e práticas destinadas a reinventar as maneiras de ser e conviver na sociedade, cujos valores não derivam unicamente de interesses, de lucro e consumo, mas de um senso comum de alteridade, de resguardo e recuperação da dignidade e solidariedade, liberdade e igualdade ${ }^{97}$.

Assim, a concepção da eco cidadania encara a atualização da realidade sem estancar no passado, assumindo o propósito de transformação cultural multidimensional, como espaço para reconciliar os distintos projetos de vida, preservando o direito ao futuro, o futuro do outro, que inclui o complexo da alteridade $^{98}$.

\section{CONSIDERAÇÕES FINAIS}

Constatou-se que a incapacidade de controlar os resultados gerados pelo desenvolvimento industrial eclode em vários danos e desastres ambientais que refletem na dimensão social, e esses reflexos da política de crescimento tornam a própria população refém do efeito bumerangue, disseminando problemas socioambientais em escala global, que atingem a todos, mas castigam, sobretudo, os mais vulneráveis, demonstrando que os direitos de cunho liberal já não são suficientes para evitar, senão, provocar, a afronta à dignidade humana.

No entanto, a teoria da modernização reflexiva, além de apresentar os efeitos reflexos advindos do modelo de desenvolvimento, inspira a reflexão acerca da necessidade de mudança das regras estruturais dos sistemas vigentes que desencadeiam tantos problemas socioambientais.

Com isso, a exposição dos institutos jurídicos articulados visa 0 enfrentamento das debilidades socioambientais em caráter de controle social,

\footnotetext{
${ }^{95}$ FAGÚNDEZ, Paulo Roney Ávila. O Direito e a Hipercomplexidade. São Paulo: LTr, 2003, p. 33-34.

${ }^{96}$ WARAT, Luis Alberto. Por quien cantan las Sirenas: Informe sobre Eco-ciudadania, Género y Derecho - Incidencias del barroco en el pensamento jurídico. Florianópolis: UNOESC/CPGD-UFSC, 1996, p. 20-21.

${ }_{97}$ WARAT, Luis Alberto. Por quien cantan las Sirenas: Informe sobre Eco-ciudadania, Género y Derecho - Incidencias del barroco en el pensamento jurídico. Florianópolis: UNOESC/CPGD-UFSC, 1996, p. 21-22.

${ }^{98}$ WARAT, Luis Alberto. Por quien cantan las Sirenas: Informe sobre Eco-ciudadania, Género y Derecho - Incidencias del barroco en el pensamento jurídico. Florianópolis: UNOESC/CPGD-UFSC, 1996, p. 34-35.
} 
sobretudo diante da percepção da crise generalizada e da premência de mudanças.

Por isso, pretendeu-se demonstrar com o projeto da eco cidadania a necessidade de recuperar a preocupação com o próximo, propondo levar em consideração o caráter ideológico da alteridade ao enfrentarmos os problemas e conflitos socioambientais.

Assim, a concepção de eco cidadania apresentada por Luis Alberto Warat implica, sobretudo, em repensar as regras de mercado, percebendo o vínculo entre homens, a natureza e a sociedade, propondo uma resposta emancipatória e sustentável, para garantir nosso direito ao futuro.

\section{REFERÊNCIAS}

ACSELRAD, Henri. A Ambientalização das Lutas Sociais: o caso do movimento por justiça ambiental. Disponível em: <http://www.scielo.br/pdf/ea/v23n68/10.pdf>. Acesso em: 21 jul. 2014.

ACSELRAD, Henri. Justiça Ambiental e a Construção Social do Risco. Disponível em: <http://ojs.c3sl.ufpr.br/ojs2/index.php/made/article/viewFile/22116/14480>. Acesso em: 04 abr. 2013.

ALIER, Joan Martinez. Ecologismo dos Pobres: conflitos ambientais e linguagens de valoração. São Paulo: Contexto, 2007.

ANTUNES, Paulo de Bessa. Direito Ambiental. 7. ed., Rio de Janeiro: Lumen Juris, 2004. AYALA, Patryck de Araújo. Direito Fundamental ao Ambiente e a Proibição de Regresso nos Níveis de Proteção Ambiental na Constituição Brasileira. In: FERREIRA, Heline Sivini; FERREIRA, Maria Leonor Paes Cavalcanti (Org.). Dano Ambiental na Sociedade de Risco. São Paulo: Saraiva, 2012.

AYALA, Patryck de Araújo; WENER, Eveline de Magalhães. O Estado Socioambiental e o Dever de Proteção de Projetos de Vida Sustentáveis. Revista Direito Ambiental e Sociedade. Universidade de Caxias do Sul, vol. 1, n² 2, p. 211-228, jul./dez., Caxias do Sul, RS: Educs, 2011.

BASTOS, Frederico Silva. Controle Social da Administração Financeira do Estado: democracia, transparência e responsabilidade. Revista dos Tribunais, ano 2012, vol. 936, out. 2013.

BAUMAN, Zygmunt. Vida para Consumo: a transformação das pessoas em mercadoria. Tradução Carlos Alberto Medeiros. Rio de Janeiro: Zahar, 2008.

BECK, Ulrich. La Sociedad del Riesgo: hacia uma nueva modernidade. Título original: Risikogesellschaft. Auf dem Weg in eine andere Moderne. Barcelona: Ediciones Paidós Ibérica, S.A., 2006.

BENJAMIN, Antônio Herman. Constitucionalização do Ambiente e a Ecologização da Constituição Brasileira. In: CANOTILHO, José Joaquim Gomes; LEITE, José Rubens Morato (orgs.). Direito Constitucional Ambiental Brasileiro. São Paulo: Saraiva, 2007.

BENTES, Ivana. O Copyright da Miséria e os Discursos sobre a Exclusão. Lugar Comum, no 17, p. 85-95. Disponível em: <http://s3.amazonaws.com/academia.edu. documents/30467869/11_o_copyright_da_miseria_e_os_discursos_sobre_a_exclusao. 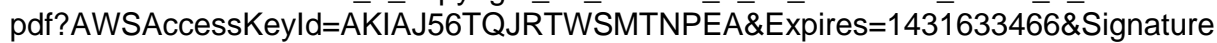 =a3jliu2UGGEVxRblwGkqH4d7EZ4\%3D\&response-content-disposition=inline>. Acesso em: 19 maio 2015. 
BENTES, IVANA. Terra de Fome e Sonho: o país material de Glauber Rocha. Disponível em: <http://www.bocc.ubi.pt/pag/bentes-ivana-glauber-rocha.html>. Acesso em 15 maio 2015; ROCHA, Glauber. Eztetyka da Fome. Disponível em: <http://www.tempoglauber. com.br/t_estetica.html>. Acesso em: 19 maio 2015.

BIANCHI, Patrícia Nunes Lima. Eficácia das Normas Ambientais. São Paulo: Saraiva, 2010. BRASIL. Secretaria de Educação Fundamental. Parâmetros Curriculares Nacionais: apresentação dos temas transversais, ética / Secretaria de Educação Fundamental. Brasília: MEC/SEF, 1997. Disponível em: <http://portal.mec.gov.br/seb/arquivos/pdf/ livro081.pdf>. Acesso: em 23 jan. 2015.

. Constituição da República Federativa do Brasil. Brasília, DF: Senado Federal, 1988.

CAPRA, Fritjof. A Teia da Vida: uma compreensão científica dos sistemas vivos. São Paulo: Editora Cultrix, 1996.

CAVEDON, Fernanda de Salles; VIEIRA, Ricardo Stanziola. Conexões entre Desastres Ecológicos, Vulnerabilidade Ambiental e Direitos Humanos: novas perspectivas. Revista de Direito Econômico e Socioambiental, Curitiba, v. 1, nº 1, p. 179-206, jan./jun. 2011.

Convenção de Aarhus sobre Acesso à Informação, Participação do Público no Processo de Tomada de Decisão e Acesso à Justiça em Matéria de Ambiental. Disponível em: $<$ http://www.unece.org/fileadmin/DAM/env/pp/EU\%20texts/conventioninportogese.pdf>. Acesso em: 15 maio 2015.

CORREA, Esmeralda. Qual a relação entre pobreza e meio ambiente? Evidências e Reflexões desde uma Perspectiva Multidimensional do Bem-estar Humano. Disponível em: <www.pucrs.br/eventos/alcadeca/download/pobreza-e-meio-ambiente.doc>. Acesso em: 23 jan. 2015.

CRUZ, Ana Paula Fernandes Nogueira da. Culpabilidade e a Responsabilidade Criminal da Pessoa Jurídica. Revista de Direito Ambiental, v. 9, n 35, p. 123-154. jul./set. São Paulo: Revista dos Tribunais, 2004.

CRUZ, Paulo Márcio; BODNAR, Zenildo. Globalização, Transnacionalidade e Sustentabilidade. Itajaí: UNIVALI, 2012. Disponível em: <http://uww.univali.br/ppcj/ebook>. Acesso em: 21 jul. 2014.

CUNHA JUNIOR, Dirley da. Curso de Direito Administrativo. Salvador: Juspodivm, 2015.

Declaração da Conferência da Organização das Nações Unidas (ONU) sobre Meio Ambiente Humano de Estocolmo de 1972. Disponível em: <http://www.apambiente.pt/ _zdata/Politicas/DesenvolvimentoSustentavel/1972_Declaracao_Estocolmo.pdf>. Acesso em: 15 maio 2015.

Declaração do Rio de Janeiro de 1992. Disponível em: <http://www.onu.org.br/rio20/ img/2012/01/rio92.pdf>. Acesso em: 15 maio 2015.

DEMAJOROVIC, Jacques. Sociedade de Risco e Responsabilidade Socioambiental: perspectivas para a educação corporativa. São Paulo: Editora Senac, 2003.

DEMO, Pedro. Direitos Humanos e Educação: pobreza política como desafio central. Brasília: UNB, 1999. Disponível em: <http://www.dhnet.org.br/educar/textos/demo_ direitos_humanos_e_educacao.pdf>. Acesso em: 24 out. 2014.

. Charme da Exclusão Social. Campinas, SP: Autores Associados, 1998.

Diário de Santa Maria, Grupo RBS. Senegalês tem o corpo queimado enquanto dormia em Santa Maria. Três homens jogaram fogo no colchão do imigrante, que teve 
queimaduras superficiais nas duas pernas. Disponível em: <http://diariodesantamaria. clicrbs.com.br/rs/geral-policia/noticia/2015/09/senegales-tem-o-corpo-queimado-enquantodormia-em-santa-maria-4846594.html>. Acesso em: 20 out. 2015.

FAGÚNDEZ, Paulo Roney Ávila. O Direito e a Hipercomplexidade. São Paulo: LTr, 2003. FANTÁSTICO, G1. Milhares de estrangeiros buscam oportunidades no Brasil. Disponível em: <http://g1.globo.com/fantastico/videos/t/edicoes/v/milhares-de-estrangeirosbuscam-oportunidades-no-brasil/3570062/>. Acesso em: 20 out. 2015.

FENSTERSEIFER, Tiago. Direitos Fundamentais e Proteção do Ambiente: a dimensão ecológica da dignidade humana no marco jurídico-constitucional do Estado Socioambiental de Direito. Porto Alegre: Livraria do Advogado Editora, 2008.

FIORILLO, Celso Antonio Pacheco. Fundamentos Constitucionais do Meio @mbiente Digit@I na Sociedade da Informação. In: PAESANI, Liliana. O Direito na Sociedade da Informação III: A evolução do direito digital, v. 3, Atlas, 2013. VitalBook file. Minha Biblioteca. Disponível em: <http://online.minhabiblioteca.com.br/books/9788522482139>. Acesso em: 09 set. 2014.

FREIRE-MEDEIROS, Bianca. A Favela e seus Trânsitos Turísticos. Observatório de Inovação do Turismo - Revista Acadêmica, vol. II, $\mathrm{n}^{\circ}$ 2, jun. 2007. Disponível em: <http://bibliotecadigital.fgv.br/ojs/index.php/oit/article/view/5664>. Acesso em: 19 maio 2015.

FREITAS, Juarez. Sustentabilidade: direito ao futuro. Belo Horizonte: Editora Fórum, 2011.

G1 RS. Guaíba registra a segunda maior cheia da história no RS, 17 out. 2015. Disponível em: <http://g1.globo.com/rs/rio-grande-do-sul/noticia/2015/10/nivel-do-guaibaatinge-recorde-e-mantem-estado-de-alerta-no-rs.html>. Acesso em: 25 out. 2015.

GALEANO, Eduardo. As Veias Abertas da América Latina. Tradução de Galeano de Freitas, 12 ed., Rio de Janeiro: Paz e Terra, 1981. p. 74-77. Título original: Las Venas Abiertas de America Latina.

GIDDENS, Anthony. Mundo em Descontrole: o que a globalização está fazendo de nós. 6. ed., Tradução de Maria Luiza X. de A. Borges. Título original: Runaway World. Rio de Janeiro: Record, 2007.

GIDDENS, Anthony; BECK, Ulrich; LASH, Scott. Modernização Reflexiva: política, tradição e estética na ordem social moderna. Tradução de Magda Lopes. São Paulo: Editora da Universidade Estadual Paulista, 1997. Título original: Reflexive Modernization: politics, tradition and aesthetics in the modern social order.

HIROSHI, Setooka (Homazawa University, Japan). Increasing Inequality and Poverty Today: on the understanding of the essence of poverty. In: Fórum da Associação Mundial de Economia Política. 8. 2013. Florianópolis. Painel Inequality in Latin America.

JACOBI, Pedro. Educar na Sociedade de Risco: o desafio de construir alternativas. Faculdade de Educação da USP e PROCAM-USP. Revista em Educação Ambiental, v. 2, no 2, p. 49-65, 2007. Disponível em: <http://www.revistas.usp.br/pea/article/view/ 30029>. Acesso em: 06 dez. 2014.

LEITE, José Rubens Morato; BELCHIOR, Germana Parente Neiva. Dano Ambiental na Sociedade de Risco: uma visão introdutória. Dano Ambiental na Sociedade de Risco: uma visão introdutória. In: FERREIRA, Heline Sivini; FERREIRA, Maria Leonor Paes Cavalcanti (Org.). Dano Ambiental na Sociedade de Risco. São Paulo: Saraiva, 2012. 
LEITE, José Rubens Morato. Dano Ambiental: do individual ao coletivo extrapatrimonial. São Paulo: Revista dos Tribunais, 2000.

LESSA, Daniela. Mapa mostra como a injustiça ambiental afeta a saúde coletiva no país. FIOCRUZ - Fundação Osvaldo Cruz: uma instituição à serviço da vida. Disponível em: <http://portal.fiocruz.br/pt-br/content/injusti\%C3\%A7a-ambiental-afetasa\%C3\%BAde-coletiva>. Acesso em: 23 jan. 2015.

LEVY, Rafael Vivan. Não. Não existe uma Crise Migratória na Europa! E por que devemos parar de usar esse termo. Observatório 9474. Disponível em: <https://observatorio 9474.wordpress.com/2015/09/10/nao-nao-existe-uma-crise-migratoria-na-europa-e-porque-devemos-parar-de-usar-esse-termo/>. Acesso em: 01 nov. 2015.

LOPES, Ana Maria D'Avila. O Direito Fundamental à Biodiversidade e o Patenteamento de Espécies Vivas. Revista de Informação Legislativa, v. 43, nº 172, p. 57-72, out./dez. 2006. Disponível em: <http://www2.senado.leg.br/bdsf/bitstream/handle/id/92830/Lopes\% 20Ana\%20Maria.pdf?sequence=4>. Acesso em: 21 jul. 2014.

LÖWY, Michael. Ecologia e Socialismo. Brasil de Fato: uma visão popular do Brasil e do mundo. Disponível em: <http://www.brasildefato.com.br/node/4023>. Acesso em: 07 out. 2015.

MACHADO, Paulo Affonso Leme. Direito Ambiental Brasileiro. 16. ed., São Paulo: Malheiros, 2008.

MAGNO, Patricia. Refugiado, Cidadão Universal: uma análise do direito à identidade pessoal. Lugar Comum, $\mathrm{n}^{\circ}$ 27, p. 185-225. Disponível em: <http://uninomade.net/wpcontent/files_mf/110810120851Refugiado\%20Cidadao\%20Universal\%20uma\%20analise \%20do\%20direito\%20a\%20identidade\%20pessoal\%20-\%20Patricia\%20Magno.pdf>. Acesso em: 27 set. 2015.

MILESKI, Hélio Saul. Controle Social: um aliado do controle oficial. Interesse Público, ano 8, n 36, mar./abr. 2006, Porto Alegre: Notadez, p. 85-98.

MUKAI, Toshio. A Responsabilidade Civil e Penal no Campo do Direito Ambiental. In: SILVA, Bruno Campos da (Org.). Direito Ambiental: enfoques variados. São Paulo: Lemos \& Cruz, 2004.

Notícias do Dia. Justiça proíbe construções no Canto do Morcego, em Itajaí. Publicado em: 02 out. 2014. Disponível em: <http://ndonline.com.br/vale/noticias/202448-justicaproibe-construcoes-no-canto-do-morcego-em-itajai.html>. Acesso em: 19 maio 2015.

OBSERVATÓRIO DE FAVELAS. Do "perigoso" ao Exotismo: faces da mesma moeda. Disponível em: <http://observatoriodefavelas.org.br/noticias-analises/do-perigo-aoexotismo-faces-da-mesma-moeda/>. Acesso em: 25 maio 2015.

O Sol Diário. Abraço ao Canto do Morcego reúne centenas de pessoas em Itajaí. Publicado em: 24 ago. 2014. Disponível em: <http://osoldiario.clicrbs.com.br/sc/noticia/ 2014/08/abraco-ao-canto-do-morcego-reune-centenas-de-pessoas-em-itajai-4582413.html>. Acesso em: 19 maio 2015.

PASTANA, Débora Regina. Cultura do Medo e Democracia: um paradoxo brasileiro. Disponível em: <http://www.uel.br/revistas/uel/index.php/mediacoes/article/download/ 2172/18>. Acesso em: 28 abr. 2015.

PAULI, Gunter. Emissão Zero - a busca por novos paradigmas: o que os negócios podem oferecer à sociedade? Tradução José Wagner Maciel Kaehler; Maria Tereza Raya Rodriguez. Porto Alegre: EDIPUCRS, 1996. 
Redação Band SC. Gravação do quadro 'Proteste Já' do programa CQC em prol da Estrada da Rainha. Publicado em: 22 maio 2014. Disponível em: <http://www.bandsc. com.br/canais/materia-view.html?id=15824>. Acesso em: 19 maio 2015.

Relatório da Comissão Mundial sobre Meio Ambiente em 1987, intitulado "Nosso Futuro Comum". Disponível em: <http://www.un.org/documents/ga/res/42/ares42-187.htm>. Acesso em: 15 maio 2015.

ROCHA, Glauber. Eztetyka da Fome. Disponível em: <http://www.tempoglauber.com.br/ t_estetica.html>. Acesso em: 19 maio 2015.

RTP Notícias. Amnistia Internacional denuncia "barricadas da fortaleza Europa" face aos refugiados sírios. Disponível em: <http://www.rtp.pt/noticias/mundo/amnistia-internacionaldenuncia-barricadas-da-fortaleza-europa-face-aos-refugiados-sirios_n703074>. Acesso em: 17 set. 2015.

SEGUIN, Élida. Vitimização Ambiental. Disponível em: <http://www.arnaudeaguiar.com.br/ 2016/index.php?option=com_content\&view=article\&id=331:vitimizacao-ambiental\&catid =50\&ltemid=427\&lang=pt>. Acesso em: 26 mar. 2015.

SILVA, Brisa Arnoud da Silva. A Importância do Mínimo Existencial Ecológico para a Concretização do Estado Democrático de Direito. Revista Justiça do Direito, v. 28, no 1, p. 84-107, jan./jun. 2014. Disponível em: <www.upf.br/seer/index.php/rjd/article/ download/4832/3259>. Acesso em: 12 maio 2015.

SILVA, Brisa Arnoud da. A Sociedade da Informação a Favor da Democracia: o direito da informação e livre escolha no consumo de alimentos transgênicos. Publicatio UEPG: Ciências Sociais Aplicadas, Ponta Grossa, 23 (1): p. 103-120, jan./jun. 2015, p. 106-106. Disponível em: <http://www.revistas2.uepg.br/index.php/sociais/article/ view/7158/4623>. Acesso em: 07 nov. 2015.

SILVA, Brisa Arnoud da Silva. Do Estado Liberal para Socioambiental de Direito: o caminho para o desenvolvimento sustentável. In: SOUZA, Maria Claudia da Silva Antunes de; ARMADA, Charles Alexandre Souza (Org.). Teoria Jurídica e Transnacionalidade, vol. II. Disponível em: <http://www.univali.br/ppcj/ebook>. Acesso em: 21 jul. 2014.

SILVA, Brisa Arnoud da Silva; RONCONI, Elizangela Pieta. Em Busca da Superação do Complexo de Vira-lata: o fortalecimento do Estado Socioambiental no espaço transnacional. In: GARCIA, Denise Schmidtt Siqueira. Debates Sustentáveis: análise multidimensional e governança ambiental. p. 31-53. Itajaí: UNIVALI, 2015. Disponível em: <http://www.univali.br/ppcj/ebook>. Acesso em: 20 maio 2015.

VIEIRA, Liszt. Os Argonautas da Cidadania: a sociedade civil na globalização. Rio de Janeiro: Editora Record, 2001.

VIOLA, Eduardo; LEIS, Héctor R. Mudanças na Direção de uma Globalização Multidimensional Complexa. Cadernos de Pesquisa Interdisciplinar em Ciências Humanas, $\mathrm{n}^{\circ}$ 40, nov. 2002. Disponível em: <https://periodicos.ufsc.br/index.php/ cadernosdepesquisa/article/view/1112>. Acesso em: 06 out. 2015. 